\title{
Rancangan Alat Kontrol Pemadam Kebakaran Otomatis Berbasis Mikrokontroler Arduino Mega Dengan Menggunakan Sensor Asap, Suhu dan HMI (Human Machine Intrface) di Bandar Udara
}

\author{
Kustori \\ Program Studi Diploma III Teknik Listrik Bandar Udara \\ Politeknik Penerbangan Surabaya \\ Jl. Jemur Andayani 1/73 Wonocolo Surabaya 60236 \\ Telp.(031)841087, Fax.(031)8490005
}

\begin{abstract}
Abstraksi
Pemadam kebakaran selama ini di Bandar Udara ditanggulangi oleh petugas pemadamkebakarandan belum di bangunnya alat kontrol pemadam kabakaran secara terintegrasi di ruang Terminal Bandara menyebabkan berbagai permasalahan dalam pelayanan jasa pada Bandar Udara sehingga dengan adanya alat pemadam kebakaran otomatis yang menggunkan HMI (Human Machine Interface) di Bandar Udara ini dapat menang gulangi permasalahan selama ini di Bandar Udara. Permasalahan yang di kaji dalampenulisan tugas akhir ini adalah belum di bangunnya alat kontrol pemadam kebakaran yang terintegrasi menggukan HMI (Human Machine Interface) pada Bandar Udara. Penulisan tugas akhir ini bertujuan untuk mendapat suatu rancangan alat pemadam kebakaran otomatis yang menggunakan HMI (Human Machine Interface) di Bandar Udara. Pemadam kebakaran otomatis yang menggunkan HMI (Human Machine Interface) merupakan suatu rancangan alat yang mengunakan sensor sebagai detektor bahwa adanya bahaya pemicu kebakaran dan mikrokontroler sebag a i pu sat pengelolah data dan sebagai ek sekusinya digunakan pompa dan springkler untuk memadamkan api, HMI ( Human Machine Interface) disini digunakan untuk memudahkan pengontrolan langsung pada peralatan kebaka ran serta ruangan tempat terjadi kebakaran. Selain itu tujuan dari penulisan tugas akhir ini adalah untuk mene rapkan ilmu yang telah diperoleh selama mengikuti pendidikan di Akademi Teknik dan Keselamatan Penerbangan Surabaya. Dari hasil pengujian alat maka dengan adanya alat pemadam kebakaran otomatis yang menggunakan HMI (Human Machine Interface) dapat menanggulangi permasalahan dan memenuhi kebutuhan akan kenyamanan dan keamanan dalampenyediaan jasa penerbangan di Bandar Udara.

Kata-Kata Kunci: Human Machine Intrface, Antarmuka pengguna, antarmuka manusia-komputer dan antarmuka manusia-mesin
\end{abstract}

\section{PENDAHULUAN \\ Latar Belakang}

Kemajuan transportasi udara dalam melayani masyarakat di dunia penerbangan sekarang semakin pesat dengan di bangunnya bandar Udara. Bandar Udara dalam meningkatkan pelayanannya untuk memberikan jasa kepada pengguna jasa penerbangan di bandara maka Bandar Udara siap meningkatkan mutu pelayanan dalam peyediaan jasa salah satu hal yang tidak kala pentingnya adalah dalam memberikan rasa aman bagi pengguna jasa pelayanan bila terjadi hal yang tidak di inginkan seperti kebakaran. Kebutuhan akan penumpang, bahan bagunan, alat berat, kendaraan bermotor dan bahan makanan sertake butuhan-kebutuhan lainnya didatangkan melalui pesawat udara. Penerbangan yang dilayani oleh BandarUdara, yang membawa penyediaan barang ke setiap daerah. Sehingga dalam penyediaan jasa dan kesibukan yang terjadi saat ini Bandar Udara telah di bangun bandara yang baru yang dilengkapi dengan fasilitas-fasilitas yang memadahi sesuai acuan ICAO ( International Civil Aviation Organitation) annex 14 "Aerodrome" dan juga sesuai dengan Undang-Undang Nomor 1 Tahun 2009 Tentang Penerbangan dari sisi Bandar Udara, Pasal 219-221 yang mengatur tentang Fasilitas Bandar Udara yang dikelolah oleh Badan Usaha Bandara atau Unit Penyelenggara Bandar Udara, oleh sebab itu Badan Penyelenggara Bandar Udara saat ini telah membangun beberapa fasilitas bandara yang meliputi fasilitas airside dan landside. 
1. Apron adalah tempat parkir pesawat yang dekat dengan bangunan terminal, sedangkan taxiway menghubungkan apron dan run-way pembangunan saat ini di Bandar Udara apron sendiri telah dibangun dengan dua gate kedatangan dan keberangkatan.

2. Air Tarffic Control (ATC) sebagai pemandu pergerakan pesawat diudara saat ini sudah ada dan berfungsi mengatur semua traffic yang ada di Bandar udara.

3. Air Rescue Service (pemadam Kebakaran). Pada Bandar Udara sudah ada penanggulangan kecelakaan (air rescue service) pemadam kebakaran, mobil pemadam kebakaran, tabung pemadam kebakaran, ambulance, peralatan penolong dan pemadam kebakaran yang di tangani oleh petugas PK-PPK (Pertolongan Kecelakaan Penerbangan Pemadam Kebakaran).

Fasilitas landside terdiri dari Terminal Bandar Udara yang dibangun dengan luas terminal $600 \mathrm{~m}$, Bandara kini dapat menampung hingga 228 penumpang dengan fasilitas lengkap seperti, 5 buah konter check-in, kursi penumpang di ruang boarding, ruangan ber-AC, dan toilet. Curb tempat penumpang naikturun dari kendaraan darat ke dalam bangunan terminal parkir kendaraan, untuk parkir para penumpang dan pengantar atau penjemput, termasuk taksi

Dari pembanguan fasilitas-fasilitas yang telah di bangun terdapat beberapa alat pendukung lain yang belum di bangun seperti pemadaman api terintegrasi dan Flight Information System Display (FIDS) disebabkan karena kurangnya alat dan minimnya SDM (sumber daya manusia) yang dimiliki oleh Bandar Udara. pembangunan bandara baru ini pemadaman kebakaran sendiri dilakukan oleh pihak petugas Dinas Pemadam Kebakaran dalam menanggulangi kebakaran yang terjadi. Akibat kejadian kebakaran ini kantor KPP, ruang Kesehatan Bandara dan Gudang Bagasi, loket penjualan tiket, serta lainnya hangus terbakar yang disebabkan karena hubungan arus pendek listrik atau konsleting menjadi penyebab kebakaran akibatnya kerugian yang terjadi mencapai ratusan juta hingga miliyaran rupiah.

Dari latar belakang yang telah dijelaskan diatas, maka penulis tergerak untuk membuat suatu rancangan alat yang dapat menanggulangi kebakaran ketika terjadi kebakaran dan dapat di aplikasikan langsung pada keadaan bandara saat ini . dengan judul tugas akhir yaitu "Rancangan Alat Kontrol Pemadam Kebakaran Otomatis Berbasis Mikrokontroler Arduino Mega Dengan Mengunakan Sensor Asap, Suhu dan HMI (Human Machine Interface) di Bandar Udara”.

Pada Bandar Udara sehingga kedepannya jika terjadi kebakaran maka, kerugian yang ditimbulkan bisa diminimalisir dan juga memberikan rasa aman kepada pengguna jasa pelayanan Bandar Udara.

\section{LANDASAN TEORI \\ Mikrokontroler}

Mikrokontroler adalah sebuah sistem komputer fungsional dalam sebuah chip. Di dalamnya terkandung sebuah inti prosesor, memori (sejumlah kecil RAM, memori program, atau keduanya), dan perlengkapan input output.

Dengan kata lain, mikrokontroler adalah suatu alat elektronika digital yang mempunyai masukan dan keluaran serta kendali dengan program yang bisa ditulis dan dihapus dengan cara khusus, cara kerja mikrokontroler sebenarnya membaca dan menulis data. Mikrokontroler merupakan komputer didalam chip yang digunakan untuk mengontrol peralatan elektronik, yang menekankan efisiensi dan efektifitas biaya. Secara harfiahnya bisa disebut "pengendali kecil" dimana sebuah sistem elektronik yang sebelumnya banyak memerlukan komponen-komponen pendukung seperti IC TTL dan CMOS dapat direduksi/diperkecil dan akhirnya terpusat serta dikendalikan oleh mikrokontroler ini. (http://www.kelasmikrokontrol)

\section{Sensor}

Sensor merupakan bagian dari transducer yang berfungsi untuk melakukan sensing atau "merasakan dan menangkap" adanya perubahan energi eksternal yang akan masuk ke bagian input dari transducer, sehingga perubahan kapasitas energi yang ditangkap segera dikirim kepada bagian konvertor dari transducer untuk dirubah menjadi energi listrik. Berikut adalah macam - macam sensor : 
1. Sensor cahaya adalah alat yang digunakan untuk merubah besaran cahaya menjadi besaran listrik. Prinsip kerja dari alat ini adalah mengubah energi foton menjadi elektron. Salah satu penggunaannya yang paling populer adalah kamera digital.

2. Sensor suhu adalah alat yang digunakan untuk merubah besaran panas menjadi besaran listrik. Ada beberapa metode yang digunakan untuk membuat sensor ini, salah satunya dengan cara menggunakan material yang berubah hambatannya terhadap arus listrik sesuai dengan suhunya.

Alarm

Alarm secara umum dapat didefinisikan sebagai bunyi peringatan atau pemberitahuan. Dalam istilah jaringan, alarm dapat juga didefinisikan sebagai pesan berisi pemberitahuan ketika terjadi penurunan atau kegagalan dalam penyampaian sinyal komunikasi data ataupun ada peralatan yang mengalami kerusakan (penurunan kinerja). Pesan ini digunakan untuk memperingatkan operator mengenai adanya masalah (bahaya) pada jaringan. Alarm memberikan tanda bahaya berupa sinyal, bunyi, ataupun sinar.

\section{Pompa}

Pompa adalah alat untuk menggerakan cairan atau adonan. Pompa menggerakan cairan dari tempat bertekanan rendah ke tempat dengan tekanan yang lebih tinggi, untuk mengatasi perbedaan tekanan ini maka diperlukan tenaga (energi). Pompa untuk udara biasa disebut Kompresor, kecuali untuk beberapa aplikasi bertekanan rendah, seperti di Ventilasi, Pemanas, dan Pendingin ruangan maka sebutanya menjadi fan atau Penghembus (Blower) Pompa beroperasi dengan prinsip membuat perbedaan tekanan antara bagian masuk (suction) dengan bagian keluar (discharge). Dengan kata lain, pompa berfungsi mengubah tenaga mekanis dari suatu sumber tenaga (penggerak) menjadi tenaga kinetis (kecepatan), dimana tenaga ini berguna untuk mengalirkan cairan dan mengatasi hambatan yang ada sepanjang pengaliran

\section{Sistem HMI (Human Machine Interface)}

Human Machine Interface (HMI) adalah sistem yang menghubungkan antara manusia dan teknologi mesin.HMI dapat berupa pengendali dan visualisasi status baik dengan manual maupun melalui visualisasi komputer yang bersifat real time. Port yang biasanya digunakan untuk kontroler dan akan dibaca oleh HMI antara lain adalah port com, port USB, port RS232 dan ada pula yang menggunakan port serial.

\section{PERANCANGAN DAN PEMBUTAN ALAT Kondisi Yang di Inginkan}

Kondisi yang dinginkan saat ini adalah dengan membangunnya sebuah alat kontrol pemadam kebakaran terintegrasi pada terminal Bandar udara yang akan diaplikasikan langung pada kebutuhan Bandar Udara. Oleh sebab itu perancangan alat sendiri meliputi beberapa tahapan Terdapat dua jenis tahap perancangan sistem pemadam kebakaran otomatis dalam Tugas Akhir ini yaitu perancangan perangkat keras (hardware) dan perancangan perangkat lunak (software). Perancangan ini dimaksudkan untuk mengetahui kondisi secara umum.

Berikut adalah gambar denah bangunan terminal bandara yang akan dirancang untuk pemasangan alat kontrol pemadam kebakaran otomatis 


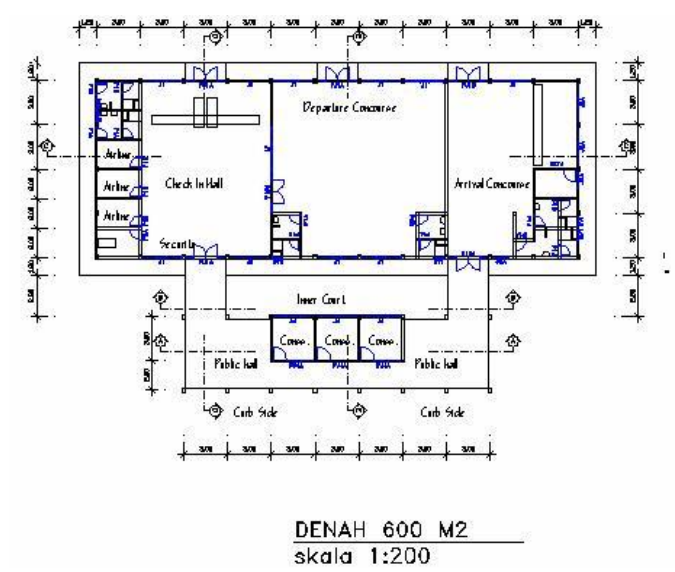

Gambar 1. Denah Bangunan Bandara

\section{Konsep Rancangan Alat}

Rancangan alat dalam bab ini akan di bahas bagaimana alat di rancangan terlebih dahulu kita melihat konsep yang akan di rancang. Dengan kondisi saat ini penulis mencoba merancang suatu sistem pengontrolan terpusat untuk memudahkan teknisi dalam melakukan kontrol terhadap alat pemadam kebakaran dan kejadian kebakaran pada setiap ruangan diterminal bandara

Pe rancangan Pe rangkat Ke ras (Hardware)

a) Pemasangan rangkaian sensor suhu Lm 35 dan sensor Asap pada arduino Mega 256
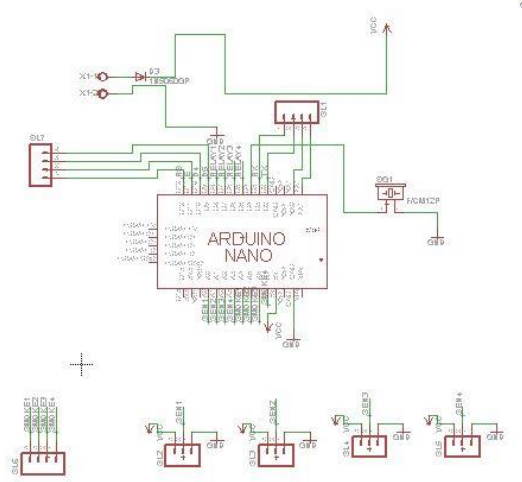

Gambar 2. Rangkain Sensor Suhu dan Sens or Asap pada Arduino Mega 2560

b) Pemasangan Rangakaian Pompa Wiper dengan Relay Menggunakan ADC pada Ardunio Mega 2560

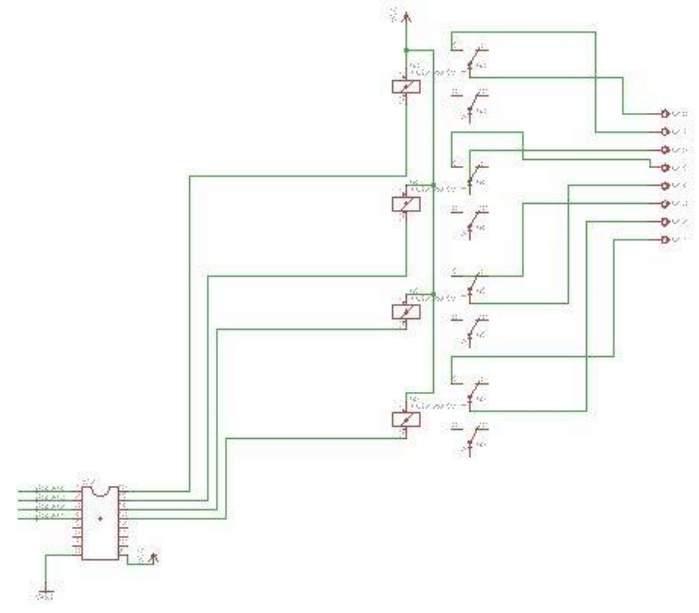

Gambar 3. Rangkaian Pompa Wiper dengan Relay Menggunakan ADC 
c) Pemasangan rangkaian Adaptor AC - DC

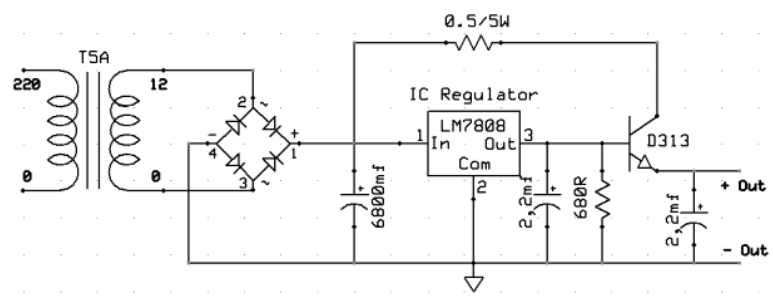

Gambar 4. Rangkaian Adaptor AC-DC 12 volt

d) Pemasangan springkler air

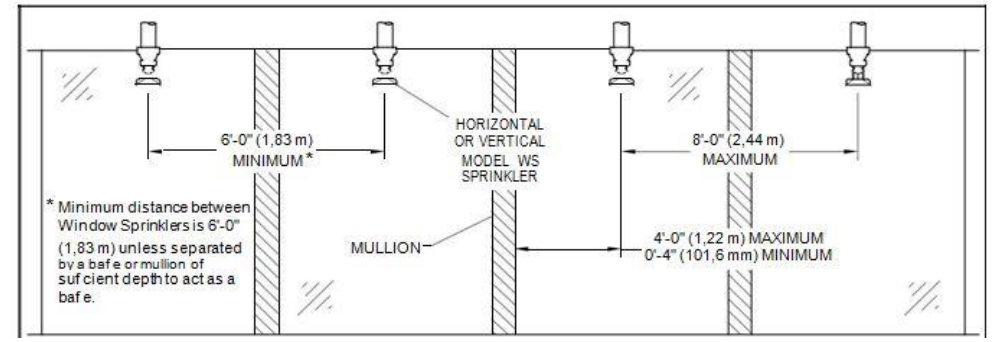

Gambar 5. Rangkaian Springkler

\section{Perancangan pe rangkat lunak (software)}

Penulisan Bahasa C pada Aplikasi Arduino Bahasa C++ digunakan untuk pemogramkan peralatan hardware agar dapat bekerja sesuai perintah yang ditulis dalam aplikasi arduino pada peralatan ini penulis menggunakan standar penulisan dalam aplikasi arduino untuk memerintah sensor dan pompa bekerja sesuai keiginan

\section{Konsep Blog Diagram Rancangan}



\section{Gambar 6. Blog Diagram Pe rancangan Alat}

1. Input Equipment, yang terdir dari rangkaian input detector . Pada rangkaian input derdapat dua detektor yaitu: Sensor asap yang berfungsi untuk mendeteksi adanya asap, dan Sensor Suhu yang berfungsi untuk mendeteksi panas atau suhu pada ruangan.

2. Main Input, terdiri dari rangkaian adaptor AC - DC yang merubah tegangan AC 220 Volt menjadi 12 Volt DC sesuai kebutuhan alat, rangakain relay 12 volt DC sebagai saklar, mikrokontroller 
Arduino Mega 2560 sebagai control utama yang akan memberikan perintah dan menjalangkan perangkat hardware setelalah mengolah data dari input equitment, rangakaian ADC sebagai

3. Output Equipment, yang terdiri dari output penanda kebakaran rangakian alarm fire yang berfungsi unutk memberi pertanda kepada orang yang berada diruangan bahwa akan terjadi kebakaran, output pemadam kebakaran berupa pompa dan springkler yang berfungsi untuk memadamkan api ketika terjadi kebakaran.

4. Control Panel, HMI (Human Machine Interface), sebagai pengendali dan visualisasi status baik dengan manual maupun melalui visualisasi computer yang bersifat realtime, yang bertujuan untuk meningkatkan interaksi antara mesin dan operator melalui tampilan layar computer dan memenuhi kebutuhan pengguna terhadap informasi sistem.

\section{Flow Chart Rancangan}

Diagram alir pemadam kebakaran adalah suatu metode untuk menggambarkan aliran proses atau prinsip kerja system hubungan sensor asapdan sensor suhu terhadap peralatan keluaran

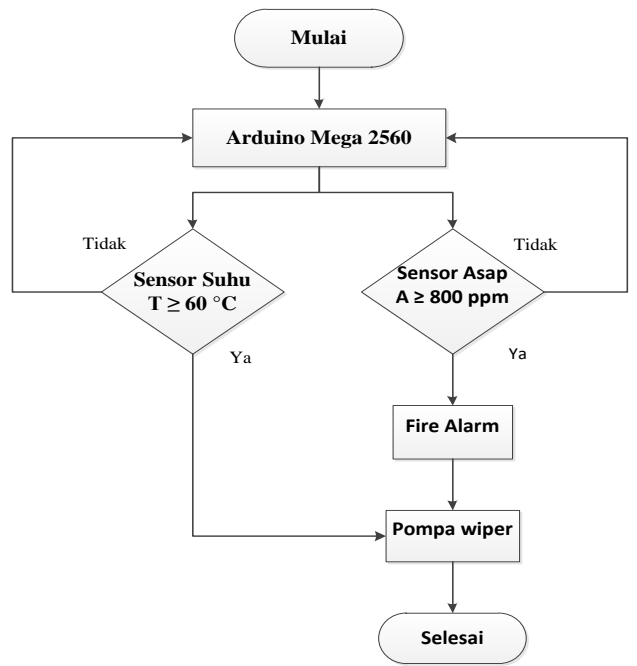

Gambar 7. Flow Chart Rancangan yang diinginkan

\section{Sistem HMI (Human Machine Interface)}

Sistem control berbasis Mikrokontroler dapat memudahkan user dalam proses monitoring dan pengontrolan sehingga dapat menjadi HMI (Human Machine Interface) antara operator (manusia) dengan mesin. HMI berfungsi sebagai jembatan bagi manusia dengan operator untuk memahami proses yang terjadi pada mesin. Adapun proses integrasi HMI dan Mikrokontroller dapatdilihat pada gambar dibawah ini

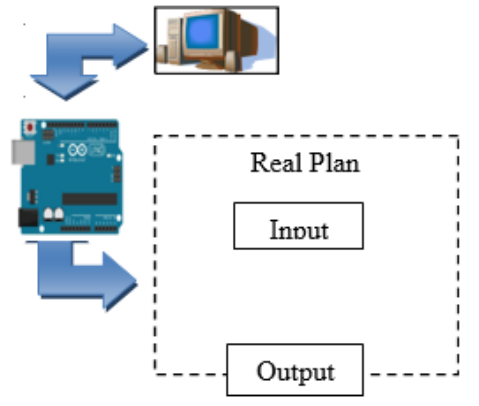

\section{Gambar 8. Racangan Human Machine Intercafe}


Gambar diatas menunjukan masing - masing bagian saling di hubungkan Sebagai suatu sistem yang terintegrasi. Mulai dari data pada input real plan di kirimkan ke Mikrokontroler untuk diolah dan di eksekusi sesuai program yang telah dirancang, kemudian data tersebut dibaca oleh computer dengan bantuan HMI.

\section{PENGUKURAN DAN ANALISA ALAT \\ Pengujian dan analisa Adaptor $A C-D C$}

1. Data Pengujian Adaptor AC - DC

Setelah dilakukan pengujian maka didapat hasil sebagaiberikut :

Tabel 1. Hasil Pengukuran Adaptor AC-DC

\begin{tabular}{|c|c|c|c|}
\hline $\begin{array}{c}\text { Tegangan input } \\
\text { Adaptor }(V) A C\end{array}$ & $\begin{array}{c}\text { Tegangan } \\
\text { Output Adaptor } \\
(V) D C\end{array}$ & $\begin{array}{c}\text { Tegangan output pada } \\
\text { sensor Smoke Detectordan } \\
\text { Suhu Lm 35(V) DC }\end{array}$ & $\begin{array}{c}\text { Tegangan Output Pada } \\
\text { Pompa wiper (V) DC }\end{array}$ \\
\hline $220 \mathrm{~V}(A C)$ & $12 \mathrm{~V}(\mathrm{DC})$ & $12 \mathrm{~V}(\mathrm{DC})$ & $12 \mathrm{~V}(\mathrm{DC})$ \\
\hline
\end{tabular}

2. Analisa Adaptor AC-DC

Setelah dilakukan beberapa pengujian, penulis mendapat data bahwa tegangan output Adaptor AC $D C$ telah sesuai dengan yang dibutuhkan.

\section{Pengujian dan analisa Sensor Asap pada ruang 1, 2, 3 dan 4}

1. Data Pengujian Sensor Asap

Setelah dilakukan uji coba maka hasil data yang di dapatkan adalah sperti data di table dibawah ini.

Tabel 2. Hasil Analisa Kerja Sens or Asap

2. Analisa Sensor Asap

\begin{tabular}{|l|l|l|l|}
\hline Asap & Nilai max 800 Ppm & Pompa wiper & keterangan \\
\hline Ruang 1 & $\geq 800 \mathrm{Ppm}$ & Aktif & Nilai ADC tidak stabil \\
\hline Ruang 2 & $\geq 800 \mathrm{Ppm}$ & Aktif & Nilai ADC stabil \\
\hline Ruang 3 & $\geq 800 \mathrm{Ppm}$ & Aktif & Nilai ADC stabil \\
\hline Ruang 4 & $\geq 800 \mathrm{Ppm}$ & Aktif & Nilai ADC stabil \\
\hline
\end{tabular}

Dari hasil yang di dapatkan sebernarnya sangat memuaskan sesuai yang dikehandaki namun karena nilai ADC pada Smoke detektor pada ruang 1 tidak stabil membuat kerja alat ini kurang efektif.

\section{Pengujian dan Analisa Sensor suhu LM 35 pada Ruang 1,2,3 dan 4}

1. Data Pengujian Sensor Suhu Lm Pada uji coba sensor suhu Lm35 ini didapati hasil berupa perbedaan suhu yang terjadi pada setiap ruangan berikut adalah tabel yang diambil dari hasil pengujian:

Tabel 3. Data Suhu Sensor Lm35 Pada se tiap Ruangan

\begin{tabular}{|l|l|l|l|}
\hline Ruangan & Suhu normal 24 $\left({ }^{0} \mathrm{C}\right)$ & Suhu maksimal $60\left({ }^{0} \mathrm{C}\right)$ & Pompa wiper \\
\hline Ruangan 1 & $24^{0} \mathrm{C}$ & $\geq 60^{\circ} \mathrm{C}$ & Aktif \\
\hline Ruangan 2 & $24^{0} \mathrm{C}$ & $\geq 60^{\circ} \mathrm{C}$ & Aktif \\
\hline Ruangan 3 & $24^{\circ} \mathrm{C}$ & $\geq 60^{\circ} \mathrm{C}$ & Aktif \\
\hline Ruangan 4 & $24^{\circ} \mathrm{C}$ & $\geq 60^{\circ} \mathrm{C}$ & Aktif \\
\hline
\end{tabular}

2. Analisa Pengujian Sensor Suhu Lm 35

Sensor suhu Lm35 bekerja sesuai dengan rangkaian yang telah di rancang dan memberikan data suhu yang sesuai dengan rancangan program pada Arduino. 


\section{KESIMPULAN DAN SARAN}

\section{Kesimpulan}

Setelah merancang Rancangan Alat Kontrol Pemadam Kebakaran Otomatis Berbasis Mikrokontroller Arduino Mega dengan Menggunakan Sensor Asap, Suhu dan Human Machine Interface (HMI), maka sebagaimana yang telah dijelaskan pada bab - bab sebelumnya dapat diambil kesimpulan yaitu:

1. Dengan adanya rancangan alat control pemadam kebakaran ini maka dapat di realisasikan, Sehingga kedepannya dapat menghemat waktu dan tenaga yang diperlukan oleh seorang teknisi.

2. Dengan adanya Racangan alat Pemadam Kebakaran Otomatis ini merupakan suatu modifikasi alat pemadam kebakaran.

\section{Saran}

ada rancangan ini tentu ada beberapa hal yang belum bisa di kembangkan karena adanya batasan masalah yang disarankan:

1. Rancangan Kontrol Alat Pemadam Kebakaran Otomatis ini dibangun menggunakan system yang sangat sederhana untuk itu kedapannya sangat diperlukan pembangunan yang sangatlah kompleks dalam arti kita bisa menggunakan peralatan seperti PLC (Programmable Logic Kontrol) .

2. Tampilan Human Machine Interface pada Pengontrolan Alat Pemadam Kebakaran masih terdapat kekurangan dalam memberikan informasi untuk itu dibutuhkan sebuah Analog Digital Converter ( ADC ) yang baik .

3. Kedepannya sangat dibutuhkan pengemban lagi Alat Kontrol Pemadam Kebakaran Otomatis yang baru dan canggih dalam mendeteksi kebakaran oleh sebab itu sebagai Alat Kontrol Pemadam Kebakaran Otomatis ini sebagai equitment yang mendukung kenyamanan dalam pelayanan di Terminal Bandara.

\section{DAFTAR PUSTAKA}

Antoni, Ahmad, 1998, Kamus Lengkap Teknik, Gitamedia Press, Jakarta.

Akademi Teknik dan Keselamatan Penerbangan Surabaya, 2012, Modul Sistem Kendali Otomatis (Mikrokontroler), ATKP Surabaya, Surabaya.

Akademi Teknik dan Keselamatan Penerbangan Surabaya, 2012, Modul Sistem Catu Daya Listrik, ATKP Surabaya, Surabaya.

Istiyanto, Jazi Eko, 2013, Pengantar Elektronika dan Instrumentasi, Andi Jogyakarta, Jogyakarta.

Blocher, Richard, 2014, Dasar Elek tronika, Andi Yogyakarta, Yogyakarta.

Siswoyo, 2008, Teknik Listrik Industri Jilid 2 Untuk SMK, Direktorat Pembinaan Sekolah Menengah

Kejuruan, Direktorat Manajemen Pendidikan Dasar dan Menengah, Departemen Pendidikan Nasional, Jakarta.

Sucipto, Erwin, 1999, Fisika, Erlangga, Jakarta.

Sahat, Pakpahan, 1988, Kontrol Otomatik Teori dan Penerapan, Erlangga, Jakarta.

Willa, Lukas, 2007, Teknik Digital, Mikroprosesor dan Mikrokomputer, Informatika, Bandung. 